medRxiv preprint doi: https://doi.org/10.1101/2022.01.06.22268745; this version posted January 6, 2022. The copyright holder for this preprint (which was not certified by peer review) is the author/funder, who has granted medRxiv a license to display the preprint in perpetuity.

It is made available under a CC-BY-NC-ND 4.0 International license .

\title{
Older Adults Mount Less Durable Humoral Responses to a Two-dose COVID-19 mRNA Vaccine Regimen, but Strong Initial Responses to a Third Dose
}

Francis Mwimanzi ${ }^{1}$, Hope Lapointe ${ }^{2}$, Peter K. Cheung ${ }^{1,2}$, Yurou Sang ${ }^{1}$, Fatima Yaseen ${ }^{1}$, Gisele Umviligihozo $^{1}$, Rebecca Kalikawe ${ }^{1}$, Sneha Datwani ${ }^{1}$, F. Harrison Omondi ${ }^{1,2}$, Laura Burns ${ }^{3}$, Landon Young ${ }^{3}$, Victor Leung ${ }^{4,5}$, Siobhan Ennis ${ }^{1}$, Olga Agafitei ${ }^{1}$, Simran Basra ${ }^{1}$, Li Yi Lim ${ }^{1}$, Kurtis Ng$^{1}$, Ralph Pantophlet $^{1}$, Chanson J. Brumme ${ }^{2,4}$, Julio S.G. Montaner ${ }^{2,4}$, Mari L. DeMarco ${ }^{3,5}$, Daniel T. Holmes ${ }^{3,5}$, Janet Simons ${ }^{3,5}$, Masahiro Niikura ${ }^{1}$, Marc G. Romney ${ }^{3,5, *}$, Zabrina L. Brumme ${ }^{1,2, *}$, Mark A. $\operatorname{Brockman}^{1,2, *}$

*MAB, MGR and ZLB contributed equally

1. Faculty of Health Sciences, Simon Fraser University, Canada;

2. British Columbia Centre for Excellence in HIV/AIDS, Canada;

3. Division of Medical Microbiology and Virology, St. Paul's Hospital, Canada;

4. Department of Medicine, University of British Columbia, Canada;

5. Department of Pathology and Laboratory Medicine, University of British Columbia, Canada

\section{Corresponding Author Contact Information:}

Mark A. Brockman, Ph.D.

Professor, Faculty of Health Sciences, Simon Fraser University

8888 University Drive, Burnaby, BC, Canada, V5A 1S6

Tel: 778 782-3341; Fax: 778-782-5927; email: mark_brockman@sfu.ca 
medRxiv preprint doi: https://doi.org/10.1101/2022.01.06.22268745; this version posted January 6, 2022. The copyright holder for this preprint (which was not certified by peer review) is the author/funder, who has granted medRxiv a license to display the preprint in perpetuity.

It is made available under a CC-BY-NC-ND 4.0 International license .

\begin{abstract}
Background. Two-dose mRNA vaccines reduce COVID-19 related hospitalization and mortality, but immune protection declines over time. As such, third vaccine doses are now recommended, particularly for older adults. We examined immune response durability up to six months after two vaccine doses, and immunogenicity after a third vaccine dose, in 151 adults ranging in age from 24 to 98 years.
\end{abstract}

Methods. Specimens were collected from 81 healthcare workers (median age 41 years), 56 older adults (median 78 years) and 14 COVID-19 convalescent individuals (median 48 years), at one, three and six months following the second vaccine dose, and from $15 \mathrm{HCW}, 28$ older adults and 3 convalescent individuals at one month following a third vaccine dose. Binding antibodies to the SARS-CoV-2 spike receptor binding domain were quantified using a commercial immunoassay. Virus neutralizing activity was assessed using a live SARS-CoV-2 infection assay.

Results. Compared to healthcare workers, older adults displayed $\sim 0.3 \log _{10}$ lower peak binding antibodies one month after the second vaccine dose $(\mathrm{p}<0.0001)$ and modestly faster rates of antibody decline thereafter $(\mathrm{p}=0.0067)$. A higher burden of chronic health conditions was independently associated with faster rates of antibody decline after correction for age, sociodemographic factors, and vaccine-related variables. Peak neutralizing activity was 4-fold lower in older adults one month after the second vaccine dose $(\mathrm{p}<0.0001)$ and became undetectable in the majority of individuals by six months. One month after a third vaccine dose, binding antibodies and neutralizing activities surpassed peak values achieved after two doses in both healthcare workers and older adults, and differences between these groups were no longer statistically significant. Compared to both naïve groups, 
medRxiv preprint doi: https://doi.org/10.1101/2022.01.06.22268745; this version posted January 6, 2022. The copyright holder for this preprint (which was not certified by peer review) is the author/funder, who has granted medRxiv a license to display the preprint in perpetuity. It is made available under a CC-BY-NC-ND 4.0 International license.

convalescent individuals displayed slower rates of binding antibody decline $(\mathrm{p}<0.006)$ and maintained higher neutralizing activity six months after the second vaccine dose.

Conclusions. Immune responses to two-dose COVID-19 mRNA vaccines are overall weaker in older adults, and also decline more quickly over time, compared to younger adults. A third COVID-19 mRNA vaccine dose enhanced binding and neutralizing antibodies to levels higher than those observed after two vaccine doses, but the rate of decline of these responses should be monitored, particularly in older adults with a higher burden of chronic health conditions. 
medRxiv preprint doi: https://doi.org/10.1101/2022.01.06.22268745; this version posted January 6, 2022. The copyright holder for this preprint (which was not certified by peer review) is the author/funder, who has granted medRxiv a license to display the preprint in perpetuity.

It is made available under a CC-BY-NC-ND 4.0 International license .

\section{INTRODUCTION}

Older adults are at increased risk of lethal coronavirus disease 2019 (COVID-19) following infection with severe acute respiratory syndrome coronavirus 2 (SARS-CoV-2) ${ }^{1-3}$. While two-dose COVID-19 vaccine regimens elicit immune responses that can protect against hospitalization and death in most cases ${ }^{4-7}$, weaker vaccine-induced immunity is observed in certain groups including the elderly 8-16, leading to the recommendation that these populations be prioritized for third vaccine doses to maximize protection ${ }^{17-19}$. Vaccine-induced antibody responses also decline naturally in all individuals, which may lead to an increased risk of breakthrough SARS-CoV-2 infections ${ }^{20-22}$, particularly with the more transmissible Omicron variant (B.1.1.529) ${ }^{23-27}$. As such, booster vaccine doses are broadly recommended to maintain protection ${ }^{28-30}$.

We and others have shown that older age is associated with weaker antibody responses to two widely available mRNA vaccines, Comirnaty (BNT162b2; Pfizer/BioNTech) and Spikevax (mRNA1273; Moderna) $6,7,15,16$. Specifically, we previously characterized longitudinal humoral responses up to three months after the second COVID-19 vaccine dose in a cohort of 151 adults 24 to 98 years of age that includes COVID-19 naïve as well as convalescent individuals ${ }^{31}$. Here, we further characterize binding and neutralizing antibody responses in this cohort six months following the second vaccine dose, allowing us to estimate binding antibody decay rates over time. We also assess humoral responses one month following a third COVID-19 vaccine dose in a subset of participants.

\section{METHODS}

Study design. We conducted a prospective longitudinal cohort study in British Columbia, Canada, to examine SARS-CoV-2 specific humoral responses following vaccination with COVID-19 mRNA vaccines Comirnaty (BNT162b2; Pfizer/BioNTech) or Spikevax (mRNA-1273; Moderna). Our cohort of 151 individuals included 81 healthcare workers $(\mathrm{HCW})$ and 56 older adults (including 18 residents 
medRxiv preprint doi: https://doi.org/10.1101/2022.01.06.22268745; this version posted January 6, 2022. The copyright holder for this preprint (which was not certified by peer review) is the author/funder, who has granted medRxiv a license to display the preprint in perpetuity.

It is made available under a CC-BY-NC-ND 4.0 International license .

of long-term care or assisted living facilities) who were COVID-19 naive at study entry, and 14 COVID-19 convalescent individuals (including $8 \mathrm{HCW}$ and 6 older adults), where prior COVID-19 was determined by the presence of anti-SARS-CoV-2 $\mathrm{N}$ antibodies at study entry (see below).

Ethics approval. Written informed consent was obtained from all participants or their authorized decision makers. This study was approved by the University of British Columbia/Providence Health Care and Simon Fraser University Research Ethics Boards.

Participants and sampling. Participants were recruited at facilities operated by Providence Health Care (Vancouver) and from the community. Serum and plasma were collected prior to vaccination, one month after the first dose, one, three and six months after the second vaccine dose, and one month following a third vaccine dose. Specimens were processed same-day and frozen until analysis.

Data sources and immune measures. Sociodemographic data (age, sex, ethnicity), chronic health conditions and COVID-19 vaccination information were collected by self-report and confirmed through medical records where available. Chronic health conditions were defined as hypertension, diabetes, asthma, obesity (defined as having a body mass index $\geq 30$ ), chronic diseases of lung, liver, kidney, heart or blood, cancer, and immunosuppression due to chronic conditions or medication, to generate a total score ranging from 0-11 per participant. Vaccine-induced responses were assessed using a commercial assay to detect total antibodies targeting the spike receptor binding domain (RBD) and an in-house virus neutralization assay to detect antibodies that prevent SARS-CoV-2 infection of target cells. 
medRxiv preprint doi: https://doi.org/10.1101/2022.01.06.22268745; this version posted January 6, 2022. The copyright holder for this preprint (which was not certified by peer review) is the author/funder, who has granted medRxiv a license to display the preprint in perpetuity.

It is made available under a CC-BY-NC-ND 4.0 International license .

Binding antibody assays. We measured total binding antibodies against SARS-CoV-2 nucleocapsid (N) and spike (S) RBD in serum using the Roche Elecsys Anti-SARS-CoV-2 and Anti-SARS-CoV-2 S assays, respectively, on a Cobas e601 module analyzer (Roche Diagnostics). Following SARS-CoV-2 infection, both anti-N and anti-RBD assays should be positive, whereas post-mRNA vaccination only the anti-RBD should be positive, allowing identification of convalescent individuals. Both tests are electro-chemiluminescence sandwich immunoassays, and report results in arbitrary units $/ \mathrm{mL}(\mathrm{U} / \mathrm{mL})$, calibrated against an external standard. For the S assay, the manufacturer indicates that AU values can be considered equivalent to international binding antibody units (BAU) as defined by the World Health Organization ${ }^{32}$. For the S assay, sera were tested undiluted, with samples above the upper limit of quantification (ULOQ) re-tested at 1:100 dilution, allowing a measurement range of 0.4 - 25,000 $\mathrm{U} / \mathrm{mL}$.

Live virus neutralization assay. Neutralizing activity in plasma was examined using a live SARS-CoV2 infectivity assay in a Containment Level 3 facility. Assays were performed using isolate USAWA1/2020 (BEI Resources) and VeroE6-TMPRSS2 (JCRB-1819) target cells. Viral stock was adjusted to 50 TCID $_{50} / 200 \mu 1$ in Dulbecco's Modified Eagle Medium in the presence of serial 2-fold dilutions of plasma (from $1 / 20$ to $1 / 2560$ ), incubated at $4^{\circ} \mathrm{C}$ for 1 hour and then added to target cells in 96-well plates in triplicate. Cultures were maintained at $37^{\circ} \mathrm{C}$ with $5 \% \mathrm{CO}_{2}$ and the appearance of viral cytopathic effect $(\mathrm{CPE})$ was recorded three days post-infection. Neutralizing activity is reported as the highest reciprocal plasma dilution able to prevent CPE in all three replicate wells. Samples exhibiting only partial or no neutralization at the lowest dilution of $1 / 20$ were coded as having a reciprocal dilution of "10", defined as below the limit of quantification (BLOQ) in this assay. 
medRxiv preprint doi: https://doi.org/10.1101/2022.01.06.22268745; this version posted January 6, 2022. The copyright holder for this preprint (which was not certified by peer review) is the author/funder, who has granted medRxiv a license to display the preprint in perpetuity.

It is made available under a CC-BY-NC-ND 4.0 International license .

Statistical analysis. Comparisons of binary variables were performed using Fisher's exact test. Comparisons of continuous variables were performed using the Mann-Whitney U-test (for unpaired data) or Wilcoxon test (for paired data). Multiple linear regression was employed to investigate the relationship between sociodemographic, health and vaccine-related variables and humoral outcomes. Variables included age (per year increment), sex at birth (female as reference group), ethnicity (nonwhite as reference group), number of chronic health conditions (per number increment), type of mRNA vaccine received (Comirnaty as reference group), sampling date following the most recent vaccine dose (per day increment), interval between first and second vaccine doses (per day increment) and COVID19 convalescent status at study entry (COVID-19 naive as reference group). Half-lives of binding antibodies in serum were calculated by fitting exponential decay curves to antibody concentrations measured at one, three and six months after the second vaccine dose (for individuals with only two measurements available, the half-life was estimated by assuming exponential decay between these two points). All statistical tests were two-tailed, with $\mathrm{p}<0.05$ considered statistically significant. Analyses were conducted using Microsoft Excel and Prism v9.2.0 (GraphPad).

\section{RESULTS}

\section{Participant, vaccine and sampling details.}

Longitudinal humoral responses up to three months after the second COVID-19 vaccine dose were previously characterized in this cohort ${ }^{31}$, which includes 81 healthcare workers (HCW), 56 older adults (including 18 residents of long-term care or assisted living facilities), and 14 convalescent individuals. Here, we further characterize humoral responses six months after the second vaccine dose, and one month following a third vaccine dose. 
medRxiv preprint doi: https://doi.org/10.1101/2022.01.06.22268745; this version posted January 6, 2022. The copyright holder for this preprint (which was not certified by peer review) is the author/funder, who has granted medRxiv a license to display the preprint in perpetuity.

It is made available under a CC-BY-NC-ND 4.0 International license .

As described previously, the cohort is predominantly female (Table 1). HCW and older adults were a median of 41 and 79 years old respectively, while the convalescent group comprised eight HCW and six older adults (median 48 years of age). Older adults were predominantly (77\%) of white Ethnicity (compared to $46 \%$ of $\mathrm{HCW}$ ) and had a higher burden of chronic health conditions (a median of 1, IQR 0-2, range 0-5, compared to a median of 1, IQR 0-0, range 0-3 in HCW). All participants received two doses of a COVID-19 mRNA vaccine between December 2020 and July 2021, where the interval between doses extended up to 112 days as per Canada's decision to delay second vaccine doses due to limited vaccine supply. A total of $141(99 \%$ of $\mathrm{HCW}, 86 \%$ of older adults and $93 \%$ of convalescent individuals) received Comirnaty as their first dose, while 10 participants received Spikevax. Second dose distribution was very similar to the first, with $98 \%$ of $\mathrm{HCW}, 88 \%$ of older adults and $93 \%$ of convalescent individuals receiving Comirnaty. Note that an additional three $(3.7 \%)$ HCW and two (3.6\%) older adults developed anti-N antibodies at some point during follow-up, consistent with a breakthrough SARS-CoV-2 infection. These participants were retained in their original respective "COVID-19 naive at study entry" groups, as excluding them did not affect overall results.

At the time of writing, 46 participants had received a third mRNA vaccine dose between October and December 2021, on average 6-8 months following their second vaccine dose. Of these, $44 \%$ received Spikevax, though note that vaccine brand information is still pending for eight older adults (Table 1). For participants who received Spikevax for their third vaccine dose, individuals aged 70 years or over received a full dose, whereas those under 70 years of age received a half dose, as per Canada's guidelines. 
medRxiv preprint doi: https://doi.org/10.1101/2022.01.06.22268745; this version posted January 6, 2022. The copyright holder for this preprint (which was not certified by peer review) is the author/funder, who has granted medRxiv a license to display the preprint in perpetuity.

It is made available under a CC-BY-NC-ND 4.0 International license .

\section{Lower RBD binding antibodies are associated with older age and number of chronic health \\ conditions, but older adults nevertheless mount strong responses to a third mRNA vaccine dose.}

We measured total anti-RBD binding antibody concentrations in serum before and after immunization with one, two and three COVID-19 vaccine doses using a commercial assay (Figure 1). As reported previously ${ }^{31}$, antibody concentrations in older adults were significantly lower than those in $\mathrm{HCW}$ one month after the first vaccine dose (a median of 2.00 [IQR $1.75-2.25] \log _{10} \mathrm{U} / \mathrm{mL}$ in $\mathrm{HCW}$ versus a median of 1.50 [IQR 1.05-1.99] in older adults), as well as one month after the second vaccine dose, a timepoint that should capture peak immune responses after a two-dose series (a median of 4.02 [IQR 3.88-4.25] in HCW versus a median of 3.74 [IQR 3.49-3.91] in older adults) (Mann-Whitney Utest; both $\mathrm{p}<0.0001)$. By three months following the second vaccine dose, antibody concentrations had declined by $\sim 0.4 \log _{10}$ on average, to a median of 3.63 [IQR 3.44-3.83] in HCW versus a median 3.32 [IQR 3.04-3.56] in older Adults) (Mann-Whitney $\mathrm{p}<0.0001$ for comparison between groups). By six months following the second vaccine dose, binding antibody concentrations had declined by a further $\sim 0.3 \log _{10}$ on average, to a median of 3.30 [IQR 3.09-3.47] in HCW versus a median 2.96 [IQR 2.703.19] in older adults $(\mathrm{p}<0.0001)$. This further confirms that the binding antibody concentrations induced by COVID-19 mRNA vaccines remain significantly lower in older compared to younger adults at all time points following a two dose series.

By contrast, the binding antibody concentrations in COVID-19 convalescent individuals remained consistently higher than those in $\mathrm{HCW}$ and older adults. At all timepoints after two doses, all comparisons between convalescent individuals and older adults were statistically significant, and those between convalescent individuals and HCW were significant in about half of comparisons. For example, despite reductions in binding antibody concentrations over time in all individuals, at six 
medRxiv preprint doi: https://doi.org/10.1101/2022.01.06.22268745; this version posted January 6, 2022. The copyright holder for this preprint (which was not certified by peer review) is the author/funder, who has granted medRxiv a license to display the preprint in perpetuity.

It is made available under a CC-BY-NC-ND 4.0 International license .

months after the second vaccine dose, convalescent individuals maintained median responses of 3.50 (IQR 3.40-3.71) $\log _{10}(\mathrm{p}=0.027$ when compared to HCW; $\mathrm{p}<0.0001$ when compared to older adults). Multivariable analyses of binding antibody responses at one, three and six months following the second vaccine dose, that adjusted for sex (as studies have reported more robust immune function in females following pathogen infection and vaccination ${ }^{33}$ ), ethnicity, number of chronic health conditions, first-dose vaccine brand, dosing interval and day of specimen collection post-immunization confirmed that older age remained negatively associated with antibody concentrations at one and three months after the second vaccine dose $(p=0.0067$ and $p=0.019$, respectively, Table 2$)$. One month following the second vaccine dose for example, each decade of older age was associated with a 0.06 $\log _{10}$ lower binding antibody concentration. Furthermore, at both of these time points, a higher number of chronic health conditions was also independently negatively associated with lower binding antibody concentrations ( $p=0.011$ and $p=0.001$, respectively). One month following the second vaccine dose for example, each additional health condition was associated with an $\sim 0.1 \log _{10}$ lower response. By six months following the second vaccine dose however, older age was no longer significantly associated with binding antibody concentration. Rather, a higher number of chronic health conditions emerged as the strongest correlate of lower responses at this timepoint, where each additional condition was associated with an $0.14 \log _{10}$ lower response $(\mathrm{p}=0.0001)$. A longer interval between first and second vaccine doses was also associated with higher binding antibody responses, consistent with previous reports ${ }^{34-36}$. COVID-19 convalescent status was also associated with maintaining $\sim 0.25 \log _{10}$ higher antibody concentrations at three and six months following the second vaccine dose (both $\mathrm{p}<0.05)$, consistent with superior durability of "hybrid" immunity induced by infection followed by vaccination 37-39. 
medRxiv preprint doi: https://doi.org/10.1101/2022.01.06.22268745; this version posted January 6, 2022. The copyright holder for this preprint (which was not certified by peer review) is the author/funder, who has granted medRxiv a license to display the preprint in perpetuity.

It is made available under a CC-BY-NC-ND 4.0 International license .

In all participants, a third COVID-19 vaccine dose boosted binding antibodies to concentrations that were at least $\sim 0.3-0.4 \log _{10}$ higher than peak values observed after two doses (these magnitudes are conservative, as many samples returned values above the assay's upper limit of quantification [ULOQ])

(Figure 1). After the third vaccine dose, binding antibodies in $\mathrm{HCW}$ rose to a median of 4.36 [4.08 to $>$ ULOQ] while those in older adults rose to a median of 4.33 [4.14 to >ULOQ], a difference that was not statistically significant ( $\mathrm{p}=0.92)$. At the time of writing, only three convalescent participants had completed a post-third dose visit, all of whom mounted strong responses. Due to relatively limited numbers, multivariable analyses were not performed on post-third dose responses. Nevertheless, these univariable analyses indicate that older adults mount strong binding antibody responses to a third COVID-19 vaccine dose.

\section{Weaker virus neutralizing activity is associated with age and chronic health conditions, but older} adults nevertheless mount strong responses to a third $m R N A$ vaccine dose.

We performed live SARS-CoV-2 neutralization assays to quantify the ability of plasma to block virus infection of target cells, which may involve spike epitopes located outside the RBD ${ }^{40,41}$, at all timepoints (Figure 2). In this stringent assay, neutralizing activity is reported as the highest reciprocal plasma dilution capable of preventing viral cytopathic effects in all three replicate wells, where a reciprocal dilution of "10" indicates no or limited neutralization. As previously reported, neutralization activities following one vaccine dose were generally weak in COVID-19 naïve individuals, though one dose induced substantial neutralization in convalescent individuals (median reciprocal dilution 320). By contrast, two vaccine doses induced neutralizing activities in most participants, though at consistently lower levels in older adults. One month after the second vaccine dose, the median reciprocal dilution was 160 [IQR 80-160] in HCW versus 40 [IQR 20-80] in older adults $(\mathrm{p}<0.0001)$. By three months 
medRxiv preprint doi: https://doi.org/10.1101/2022.01.06.22268745; this version posted January 6, 2022. The copyright holder for this preprint (which was not certified by peer review) is the author/funder, who has granted medRxiv a license to display the preprint in perpetuity.

It is made available under a CC-BY-NC-ND 4.0 International license .

after the second vaccine dose, neutralization had declined by two-fold or greater on average, to a median reciprocal dilution of 40 (IQR 20-80) in HCW versus a median of 20 (IQR BLOQ-40) in older adults $(\mathrm{p}<0.0001)$. By six months after the second vaccine dose, neutralization activity had declined to below the limit of quantification (BLOQ) in more than half of participants, including $60 \%$ of $\mathrm{HCW}$ and $87 \%$ of older adults (Mann-Whitney $\mathrm{p}=0.02$ for comparison of neutralization values between groups). Though declines in neutralizing activity were also observed in convalescent participants, this group maintained significantly higher neutralization activities compared to HCW and older adults at all time points following two-dose vaccination.

Multivariable analyses confirmed that older age remained negatively associated with neutralization at one and three months after two-dose vaccination $(p=0.019$ and $p=0.008$, respectively,

Table 2). At 6 months after the second vaccine dose however, age was no longer independently associated with poorer neutralization after adjustment for other factors. COVID-19 convalescent status remained consistently associated with superior neutralization activity at all time points following twodose vaccination (all $\mathrm{p} \leq 0.0005)$.

A third COVID-19 vaccine dose boosted neutralization activities to higher levels than those seen after two doses (Figure 1), with median activities in HCW rising to 160 [IQR 120-1920]. Of note, median activities in older adults also rose to 160 [IQR 80-400], a difference that was not statistically significant compared to $\mathrm{HCW}(\mathrm{p}=0.7)$. Despite limited numbers, these results indicate that older adults mount strong neutralization responses to a third COVID-19 vaccine dose.

Vaccine-induced binding antibody responses decline over time in all individuals, but faster in those with a higher burden of chronic conditions. 
medRxiv preprint doi: https://doi.org/10.1101/2022.01.06.22268745; this version posted January 6, 2022. The copyright holder for this preprint (which was not certified by peer review) is the author/funder, who has granted medRxiv a license to display the preprint in perpetuity.

It is made available under a CC-BY-NC-ND 4.0 International license .

Longitudinal measurement of binding antibody concentrations following the second vaccine dose allowed us to visualize response decay rates (Figure 3A). Assuming exponential decay, we estimated the antibody concentration half-lives to be a median of 60 [IQR 52-75] days in HCW versus a median of 53 [IQR 44-66] days in older adults $(p=0.0067$; Figure 3B). This suggests that, in addition to mounting overall weaker responses to COVID-19 vaccination compared to younger adults, binding antibody responses in older adults also wane more quickly.

By contrast, the median half-life in convalescent individuals was 74 [IQR 61-118] days, which was significantly longer than that of $\mathrm{HCW}$ and older adults (both $\mathrm{p} \leq 0.006$; Figure 3B). In multivariable analyses however, older age did not remain a significant independent correlate of shorter antibody half-life (Table 3). Rather, each additional chronic health condition was associated with a $\sim 6$ day shorter antibody half-life $(\mathrm{p}=0.0046)$, suggesting that chronic health conditions that can accumulate with age, rather than age itself, is the primary driver of the rate of binding antibody waning in circulation over time. Notably, COVID-19 convalescent status was associated with a 34-day longer antibody half-life after adjustment for other factors $(\mathrm{p}<0.0001)$, consistent with improved durability of hybrid immunity ${ }^{37-39}$. We did not attempt to estimate neutralization half-lives, as this activity had already declined to undetectable levels in $48 \%$ of older adults by three months after the second vaccine dose, and in $67 \%$ of all participants by six months after this dose.

\section{DISCUSSION}

Our followup study confirms that binding and neutralizing antibody activities induced by COVID-19 mRNA vaccines are significantly weaker in older adults at all time points following a twodose immunization series. In multivariable analyses, a higher number of chronic health conditions was also consistently independently associated with a weaker binding antibody response after two COVID19 vaccine doses, while a longer interval between first and second vaccine doses was consistently 
medRxiv preprint doi: https://doi.org/10.1101/2022.01.06.22268745; this version posted January 6, 2022. The copyright holder for this preprint (which was not certified by peer review) is the author/funder, who has granted medRxiv a license to display the preprint in perpetuity.

It is made available under a CC-BY-NC-ND 4.0 International license .

associated with higher binding antibody responses, as previously reported ${ }^{34-36}$. We also showed that binding antibody responses decline more rapidly over time in older adults, which can be attributed to a higher number of chronic health conditions in this group. Notably, by six months following the second vaccine dose, neutralizing responses in most individuals had declined to below the limit of quantification in our assay, supporting recent public health decisions to offer third vaccine doses, particularly to priority populations, on or before this time.

By contrast, binding and neutralizing antibody responses in COVID-19 convalescent individuals who subsequently received two COVID-19 mRNA vaccine doses remained higher than those of COVID-19 naïve individuals of all ages, and that neutralization antibody responses waned at a slower rate, consistent with superior magnitude and durability of "hybrid" immunity induced by infection followed by vaccination ${ }^{37-39}$. Finally, our data revealed that a third COVID-19 vaccine dose, which was received on average between 6-8 months after the second vaccine dose, significantly enhanced binding and neutralizing antibodies in all groups, to levels higher than those observed after two vaccine doses.

Our study has several limitations. As the precise immune correlates of protection for SARSCoV-2 transmission and disease severity remain incompletely characterized ${ }^{42}$, the implications of our results on individual-level protection from SARS-CoV-2 infection and COVID-19 remain uncertain. We did not investigate vaccine-induced T-cell responses, which may play critical roles in protection against severe COVID-19, particularly in the context of variants ${ }^{43-50}$. Furthermore, our assays tested only the ancestral SARS-CoV-2 strain (Wuhan or USA-WA1/2020); assessments of SARS-CoV-2 variants including Omicron are in progress. Our study was not designed nor powered to investigate potential differences in immune responses between the two mRNA vaccines ${ }^{51,52}$. Finally, at the time of writing, post-third dose data were available for only a subset of participants, and at a single time point. 
medRxiv preprint doi: https://doi.org/10.1101/2022.01.06.22268745; this version posted January 6, 2022. The copyright holder for this preprint (which was not certified by peer review) is the author/funder, who has granted medRxiv a license to display the preprint in perpetuity. It is made available under a CC-BY-NC-ND 4.0 International license.

In conclusion, while the observation of strong binding and neutralizing antibody responses to third COVID-19 vaccine doses in older adults, including residents of long-term care, are encouraging, it will be important to closely monitor the decline in these responses over time in this population. 
medRxiv preprint doi: https://doi.org/10.1101/2022.01.06.22268745; this version posted January 6, 2022. The copyright holder for this preprint (which was not certified by peer review) is the author/funder, who has granted medRxiv a license to display the preprint in perpetuity.

It is made available under a CC-BY-NC-ND 4.0 International license .

\section{ACKNOWLEDGEMENTS}

We thank the leadership and staff of Providence Health Care, including long-term care and assisted living residences, for their support of this study. We thank the phlebotomists and laboratory staff at St. Paul's Hospital, the BC Centre for Excellence in HIV/AIDS and Simon Fraser University for assistance. Above all, we thank the participants, without whom this study would not have been possible.

\section{FUNDING}

This work was supported by the Public Health Agency of Canada through a COVID-19 Immunology Task Force COVID-19 "Hot Spots" Award (2020-HQ-000120 to MGR, ZLB, MAB), the Canadian Institutes for Health Research (GA2-177713 to MAB), the Canada Foundation for Innovation through Exceptional Opportunities Fund - COVID-19 awards (to MAB, MD, MN, RP, ZLB) and the National Institute of Allergy and Infectious Diseases of the National Institutes of Health (R01AI134229 to RP). GU and FHO are supported by Ph.D. fellowships from the Sub-Saharan African Network for TB/HIV Research Excellence (SANTHE), a DELTAS Africa Initiative [grant \# DEL-15-006]. The DELTAS Africa Initiative is an independent funding scheme of the African Academy of Sciences (AAS)'s Alliance for Accelerating Excellence in Science in Africa (AESA) and supported by the New

Partnership for Africa's Development Planning and Coordinating Agency (NEPAD Agency) with funding from the Wellcome Trust [grant \# 107752/Z/15/Z] and the UK government. The views expressed in this publication are those of the authors and not necessarily those of AAS, NEPAD Agency, Wellcome Trust or the UK government. LYL was supported by an SFU Undergraduate Research Award. MLD and ZLB hold Scholar Awards from the Michael Smith Foundation for Health Research. 
medRxiv preprint doi: https://doi.org/10.1101/2022.01.06.22268745; this version posted January 6, 2022. The copyright holder for this preprint (which was not certified by peer review) is the author/funder, who has granted medRxiv a license to display the preprint in perpetuity.

It is made available under a CC-BY-NC-ND 4.0 International license .

\section{REFERENCES}

1 Fisman, D. N., Bogoch, I., Lapointe-Shaw, L., McCready, J. \& Tuite, A. R. Risk Factors Associated With Mortality Among Residents With Coronavirus Disease 2019 (COVID-19) in Long-term Care Facilities in Ontario, Canada. JAMA Netw Open 3, e2015957, doi:10.1001/jamanetworkopen.2020.15957 (2020).

2 Chinnadurai, R. et al. Older age and frailty are the chief predictors of mortality in COVID-19 patients admitted to an acute medical unit in a secondary care setting- a cohort study. BMC Geriatr 20, 409, doi:10.1186/s12877-020-01803-5 (2020).

3 Banerjee, A. et al. Estimating excess 1-year mortality associated with the COVID-19 pandemic according to underlying conditions and age: a population-based cohort study. Lancet $\mathbf{3 9 5}, 1715$ 1725, doi:10.1016/S0140-6736(20)30854-0 (2020).

4 Sharma, O., Sultan, A. A., Ding, H. \& Triggle, C. R. A Review of the Progress and Challenges of Developing a Vaccine for COVID-19. Front Immunol 11, 585354, doi:10.3389/fimmu.2020.585354 (2020).

5 Poland, G. A., Ovsyannikova, I. G. \& Kennedy, R. B. SARS-CoV-2 immunity: review and applications to phase 3 vaccine candidates. Lancet 396, 1595-1606, doi:10.1016/S01406736(20)32137-1 (2020).

6 Baden, L. R. et al. Efficacy and Safety of the mRNA-1273 SARS-CoV-2 Vaccine. N Engl J Med 384, 403-416, doi:10.1056/NEJMoa2035389 (2021).

7 Polack, F. P. et al. Safety and Efficacy of the BNT162b2 mRNA Covid-19 Vaccine. $N$ Engl J Med 383, 2603-2615, doi:10.1056/NEJMoa2034577 (2020). 
medRxiv preprint doi: https://doi.org/10.1101/2022.01.06.22268745; this version posted January 6, 2022. The copyright holder for this preprint (which was not certified by peer review) is the author/funder, who has granted medRxiv a license to display the preprint in perpetuity. It is made available under a CC-BY-NC-ND 4.0 International license .

8 Hodgson, S. H. et al. What defines an efficacious COVID-19 vaccine? A review of the challenges assessing the clinical efficacy of vaccines against SARS-CoV-2. Lancet Infect Dis 21, e26-e35, doi:10.1016/S1473-3099(20)30773-8 (2021).

9 Abu Jabal, K. et al. Impact of age, ethnicity, sex and prior infection status on immunogenicity following a single dose of the BNT162b2 mRNA COVID-19 vaccine: real-world evidence from healthcare workers, Israel, December 2020 to January 2021. Euro Surveill 26, doi:10.2807/15607917.ES.2021.26.6.2100096 (2021).

10 Dagan, N. et al. BNT162b2 mRNA Covid-19 Vaccine in a Nationwide Mass Vaccination Setting. N Engl J Med 384, 1412-1423, doi:10.1056/NEJMoa2101765 (2021).

11 Grupper, A. et al. Reduced humoral response to mRNA SARS-CoV-2 BNT162b2 vaccine in kidney transplant recipients without prior exposure to the virus. Am J Transplant 21, 2719-2726, doi:10.1111/ajt.16615 (2021).

12 Massarweh, A. et al. Evaluation of Seropositivity Following BNT162b2 Messenger RNA Vaccination for SARS-CoV-2 in Patients Undergoing Treatment for Cancer. JAMA Oncol 7, 11331140, doi:10.1001/jamaoncol.2021.2155 (2021).

13 Monin, L. et al. Safety and immunogenicity of one versus two doses of the COVID-19 vaccine BNT162b2 for patients with cancer: interim analysis of a prospective observational study. Lancet Oncol 22, 765-778, doi:10.1016/S1470-2045(21)00213-8 (2021).

14 Chung, H. et al. Effectiveness of BNT162b2 and mRNA-1273 covid-19 vaccines against symptomatic SARS-CoV-2 infection and severe covid-19 outcomes in Ontario, Canada: test negative design study. BMJ 374, n1943, doi:10.1136/bmj.n1943 (2021). 
medRxiv preprint doi: https://doi.org/10.1101/2022.01.06.22268745; this version posted January 6, 2022. The copyright holder for this preprint (which was not certified by peer review) is the author/funder, who has granted medRxiv a license to display the preprint in perpetuity.

It is made available under a CC-BY-NC-ND 4.0 International license .

15 Collier, D. A. et al. Age-related immune response heterogeneity to SARS-CoV-2 vaccine BNT162b2. Nature 596, 417-422, doi:10.1038/s41586-021-03739-1 (2021).

16 Muller, L. et al. Age-dependent immune response to the Biontech/Pfizer BNT162b2 COVID-19 vaccination. Clin Infect Dis, ciab381, doi:10.1093/cid/ciab381 (2021).

17 Barda, N. et al. Effectiveness of a third dose of the BNT162b2 mRNA COVID-19 vaccine for preventing severe outcomes in Israel: an observational study. Lancet 398, 2093-2100, doi:10.1016/S0140-6736(21)02249-2 (2021).

18 Canaday, D. H. et al. Significantly elevated antibody levels and neutralization titers in nursing home residents after SARS-CoV-2 BNT162b2 mRNA booster vaccination. medRxiv, doi:10.1101/2021.12.07.21267179 (2021).

19 Gilboa, M. et al. Early Immunogenicity and safety of the third dose of BNT162b2 mRNA Covid19 vaccine among adults older than 60 years; real world experience. $J$ Infect Dis, doi:10.1093/infdis/jiab584 (2021).

20 Mizrahi, B. et al. Correlation of SARS-CoV-2-breakthrough infections to time-from-vaccine. Nat Commun 12, 6379, doi:10.1038/s41467-021-26672-3 (2021).

21 Goldberg, Y. et al. Waning Immunity after the BNT162b2 Vaccine in Israel. N Engl J Med 385, e85, doi:10.1056/NEJMoa2114228 (2021).

22 Levin, E. G. et al. Waning Immune Humoral Response to BNT162b2 Covid-19 Vaccine over 6 Months. $N$ Engl J Med 385, e84, doi:10.1056/NEJMoa2114583 (2021). 
medRxiv preprint doi: https://doi.org/10.1101/2022.01.06.22268745; this version posted January 6, 2022. The copyright holder for this preprint (which was not certified by peer review) is the author/funder, who has granted medRxiv a license to display the preprint in perpetuity. It is made available under a CC-BY-NC-ND 4.0 International license .

23 Doria-Rose, N. A. et al. Booster of mRNA-1273 Vaccine Reduces SARS-CoV-2 Omicron Escape from Neutralizing Antibodies. medRxiv, doi:10.1101/2021.12.15.21267805 (2021).

24 Garcia-Beltran, W. F. et al. mRNA-based COVID-19 vaccine boosters induce neutralizing immunity against SARS-CoV-2 Omicron variant. medRxiv, doi:10.1101/2021.12.14.21267755 (2021).

25 Schmidt, F. et al. Plasma neutralization properties of the SARS-CoV-2 Omicron variant. medRxiv, doi:10.1101/2021.12.12.21267646(2021).

26 Collie, S., Champion, J., Moultrie, H., Bekker, L. G. \& Gray, G. Effectiveness of BNT162b2 Vaccine against Omicron Variant in South Africa. N Engl J Med, doi:10.1056/NEJMc2119270 (2021).

27 Cele, S. et al. SARS-CoV-2 Omicron has extensive but incomplete escape of Pfizer BNT162b2 elicited neutralization and requires ACE2 for infection. medRxiv, doi:10.1101/2021.12.08.21267417 (2021).

28 Bar-On, Y. M. et al. Protection of BNT162b2 Vaccine Booster against Covid-19 in Israel. $N$ Engl J Med 385, 1393-1400, doi:10.1056/NEJMoa2114255 (2021).

29 Choi, A. et al. Safety and immunogenicity of SARS-CoV-2 variant mRNA vaccine boosters in healthy adults: an interim analysis. Nat Med 27, 2025-2031, doi:10.1038/s41591-021-01527-y (2021).

30 Falsey, A. R. et al. SARS-CoV-2 Neutralization with BNT162b2 Vaccine Dose 3. N Engl J Med 385, 1627-1629, doi:10.1056/NEJMc2113468 (2021). 
medRxiv preprint doi: https://doi.org/10.1101/2022.01.06.22268745; this version posted January 6, 2022. The copyright holder for this preprint (which was not certified by peer review) is the author/funder, who has granted medRxiv a license to display the preprint in perpetuity.

It is made available under a CC-BY-NC-ND 4.0 International license .

31 Brockman, M. A. et al. Reduced magnitude and durability of humoral immune responses to COVID-19 mRNA vaccines among older adults. J Infect Dis, doi:10.1093/infdis/jiab592 (2021).

32 Bentley, E. et al. Collaborative Study for the Establishment of a WHO International Standard for SARS-CoV-2 RNA. World Health Organization, Expert Committee on Biological Standardization, WHO/BS/2020.2402 (2020).

33 Cook, I. F. Sexual dimorphism of humoral immunity with human vaccines. Vaccine 26, 35513555, doi:10.1016/j.vaccine.2008.04.054 (2008).

34 Amirthalingam, G. et al. Serological responses and vaccine effectiveness for extended COVID-19 vaccine schedules in England. Nat Commun 12, 7217, doi:10.1038/s41467-021-27410-5 (2021).

35 Parry, H. et al. Differential immunogenicity of BNT162b2 or ChAdOx1 vaccines after extendedinterval homologous dual vaccination in older people. Immun Ageing 18, 34, doi:10.1186/s12979021-00246-9 (2021).

36 Payne, R. P. et al. Immunogenicity of standard and extended dosing intervals of BNT162b2 mRNA vaccine. Cell 184, 5699-5714 e5611, doi:10.1016/j.cell.2021.10.011 (2021).

37 Cho, A. et al. Anti-SARS-CoV-2 receptor-binding domain antibody evolution after mRNA vaccination. Nature 600, 517-522, doi:10.1038/s41586-021-04060-7 (2021).

38 Stamatatos, L. et al. (American Association for the Advancement of Science, 2021).

39 Wang, Z. et al. Naturally enhanced neutralizing breadth against SARS-CoV-2 one year after infection. Nature 595, 426-431 (2021). 
medRxiv preprint doi: https://doi.org/10.1101/2022.01.06.22268745; this version posted January 6, 2022. The copyright holder for this preprint (which was not certified by peer review) is the author/funder, who has granted medRxiv a license to display the preprint in perpetuity.

It is made available under a CC-BY-NC-ND 4.0 International license .

40 Starr, T. N. et al. SARS-CoV-2 RBD antibodies that maximize breadth and resistance to escape.

Nature 597, 97-102, doi:10.1038/s41586-021-03807-6 (2021).

41 Barnes, C. O. et al. SARS-CoV-2 neutralizing antibody structures inform therapeutic strategies. Nature 588, 682-687, doi:10.1038/s41586-020-2852-1 (2020).

42 Feng, S. et al. Correlates of protection against symptomatic and asymptomatic SARS-CoV-2 infection. Nat Med 27, 2032-2040, doi:10.1038/s41591-021-01540-1 (2021).

43 Redd, A. D. et al. Minimal cross-over between mutations associated with Omicron variant of SARS-CoV-2 and CD8+ T cell epitopes identified in COVID-19 convalescent individuals. bioRxiv, doi:10.1101/2021.12.06.471446 (2021).

44 Peng, Y. et al. An immunodominant NP105-113-B*07:02 cytotoxic T cell response controls viral replication and is associated with less severe COVID-19 disease. Nat Immunol 23, 50-61, doi:10.1038/s41590-021-01084-z (2022).

45 Swadling, L. et al. Pre-existing polymerase-specific T cells expand in abortive seronegative SARSCoV-2. Nature, doi:10.1038/s41586-021-04186-8 (2021).

46 Horiuchi, S. et al. Immune memory from SARS-CoV-2 infection in hamsters provides variantindependent protection but still allows virus transmission. Sci Immunol 6, eabm3131, doi:10.1126/sciimmunol.abm3131 (2021).

47 Grifoni, A. et al. SARS-CoV-2 human T cell epitopes: Adaptive immune response against COVID-19. Cell Host Microbe 29, 1076-1092, doi:10.1016/j.chom.2021.05.010 (2021). 
medRxiv preprint doi: https://doi.org/10.1101/2022.01.06.22268745; this version posted January 6, 2022. The copyright holder for this preprint (which was not certified by peer review) is the author/funder, who has granted medRxiv a license to display the preprint in perpetuity. It is made available under a CC-BY-NC-ND 4.0 International license.

48 Dan, J. M. et al. Immunological memory to SARS-CoV-2 assessed for up to 8 months after infection. Science 371, doi:10.1126/science.abf4063 (2021).

49 Riou, C. et al. Escape from recognition of SARS-CoV-2 Beta variant spike epitopes but overall preservation of T cell immunity. Sci Transl Med, eabj6824 (2021).

50 Keeton, R. et al. SARS-CoV-2 spike T cell responses induced upon vaccination or infection remain robust against Omicron. medRxiv, 2021.2012.2026.21268380, doi:10.1101/2021.12.26.21268380 (2021).

51 Steensels, D., Pierlet, N., Penders, J., Mesotten, D. \& Heylen, L. Comparison of SARS-CoV-2 Antibody Response Following Vaccination With BNT162b2 and mRNA-1273. JAMA 326, 15331535, doi:10.1001/jama.2021.15125 (2021).

52 Nanduri, S. et al. Effectiveness of Pfizer-BioNTech and Moderna Vaccines in Preventing SARSCoV-2 Infection Among Nursing Home Residents Before and During Widespread Circulation of the SARS-CoV-2 B.1.617.2 (Delta) Variant - National Healthcare Safety Network, March 1August 1, 2021. MMWR Morb Mortal Wkly Rep 70, 1163-1166, doi:10.15585/mmwr.mm7034e3 (2021). 


\begin{tabular}{|c|c|c|c|}
\hline Variable & $\begin{array}{c}\text { Healthcare } \\
\text { Workers } \\
(\mathbf{n}=\mathbf{8 1})\end{array}$ & $\begin{array}{l}\text { Older Adults } \\
\quad(n=56)\end{array}$ & $\begin{array}{c}\text { COVID-19 } \\
\text { Convalescent } \\
(n=14)\end{array}$ \\
\hline Age in years, median $[\mathrm{IQR}]^{\mathrm{a}}$ & $41[35-51]$ & $78[73-83]$ & $48[36-87]$ \\
\hline Female Sex, $\mathrm{n}(\%)$ & $61(75 \%)$ & $38(68 \%)$ & $10(71 \%)$ \\
\hline White/Caucasian Ethnicity, n (\%) & $37(46 \%)$ & $43(77 \%)$ & $7(50 \%)$ \\
\hline Chronic health or immunosuppressive conditions, median [IQR] & $0[0-0]$ & $1[0-2]$ & $0[0-1]$ \\
\hline Comirnaty, First mRNA Vaccine, $\mathrm{n}(\%)$ & $80(99 \%)$ & $48(86 \%)$ & $13(93 \%)$ \\
\hline Comirnaty, Second mRNA Vaccine, $\mathrm{n}(\%)$ & $79(98 \%)$ & $46(82 \%)$ & $13(93 \%)$ \\
\hline Time between first and second doses in days, median [IQR] & $97[91-102]$ & $76[45-85]$ & $112[87-118]$ \\
\hline Comirnaty, Third mRNA Vaccine, $\mathrm{n}(\%)^{\mathrm{b}}$ & $10 / 15(67 \%)$ & $7 / 28(25 \%)^{*}$ & $3 / 3(100 \%)$ \\
\hline Time between second and third dose in days, median [IQR] & 259 [218-266] & $205[158-247]$ & $164[149-180]$ \\
\hline Specimens collected pre-vaccine, $\mathrm{n}(\%)$ & $80(99 \%)$ & $49(88 \%)$ & $13(93 \%)$ \\
\hline Specimens collected one month after first dose, $\mathrm{n}(\%)$ & $79(98 \%)$ & $49(88 \%)$ & $13(93 \%)$ \\
\hline Day of specimen collection one month after first dose, median [IQR] days & $28[27-30]$ & $30[28-32]$ & $31[28-32]$ \\
\hline Specimens collected one month after second dose, $\mathrm{n}(\%)$ & $81(100 \%)$ & $55(98 \%)$ & $14(100 \%)$ \\
\hline Day of specimen collection one month after second dose, median [IQR] days & 29 [29-32] & $29[29-31]$ & $32[30-36]$ \\
\hline Specimens collected three months after second dose, $\mathrm{n}(\%)$ & $79(98 \%)$ & $53(95 \%)$ & $13(93 \%)$ \\
\hline Day of specimen collection three months after second dose, median [IQR] days & $90[90-91]$ & 90 [89-92] & 90 [87-91] \\
\hline Specimens collected six months after second dose, $\mathrm{n}(\%)$ & $78(96 \%)$ & $40(71 \%)$ & $10(71 \%)$ \\
\hline Day of specimen collection six months after second dose, median [IQR] days & $181[179-182]$ & $176[167-182]$ & $180[179-181]$ \\
\hline Specimens collected one month after third dose, $\mathrm{n}(\%)$ & $15(19 \%)$ & $28(50 \%)$ & $1(21.4 \%)$ \\
\hline Day of specimen collection one month after third dose, median [IQR] days & 30 [30-32] & 30 [29-32] & $30[29-30]$ \\
\hline
\end{tabular}

${ }^{\mathrm{a}} \mathrm{IQR}$, interquartile range

${ }^{\mathrm{b}}$ At time of writing, 3rd dose data were only available for a subset of participants, so denominators are shown.

* Vaccine brand information is pending for 8 Older Adults 
Table 2: Multivariable analyses of the relationship between sociodemographic, health and vaccine-related variables on immunogenicity measures following two-dose COVID-19 mRNA vaccination

\begin{tabular}{|c|c|c|c|c|c|c|c|c|c|c|}
\hline \multirow{2}{*}{$\begin{array}{l}\text { Humoral } \\
\text { measure }\end{array}$} & \multirow{2}{*}{ Variable } & \multicolumn{3}{|c|}{1 mo after 2 nd dose } & \multicolumn{3}{|c|}{3 mo after 2 nd dose } & \multicolumn{3}{|c|}{6 mo after 2 nd dose } \\
\hline & & Estimate & $95 \%$ CI & p-value & Estimate & $95 \%$ CI & p-value & Estimate & $95 \%$ CI & p-value \\
\hline anti-RBD & Age (per year) & -0.0061 & -0.010 to -0.0017 & 0.0067 & -0.0047 & -0.0085 to -0.00077 & 0.019 & -0.0027 & -0.0074 to 0.0021 & 0.27 \\
\hline Abs & Male sex & 0.012 & -0.14 to 0.17 & 0.88 & 0.089 & -0.052 to 0.23 & 0.21 & 0.057 & -0.088 to 0.21 & 0.44 \\
\hline \multirow[t]{6}{*}{$\left(\log _{10}\right)$} & white Ethnicity & 0.098 & -0.056 to 0.25 & 0.21 & 0.15 & 0.012 to 0.29 & 0.033 & 0.070 & -0.075 to 0.21 & 0.34 \\
\hline & \# chronic cond. (per add'l) & -0.096 & -0.17 to -0.022 & 0.011 & -0.11 & -0.18 to -0.047 & 0.001 & -0.14 & -0.21 to -0.070 & 0.0001 \\
\hline & Spikevax as first dose & 0.25 & -0.038 to 0.54 & 0.088 & 0.32 & 0.054 to 0.59 & 0.019 & 0.25 & -0.057 to 0.55 & 0.11 \\
\hline & Dose interval (per day) & 0.0034 & 0.00011 to 0.0067 & 0.043 & 0.0054 & 0.0025 to 0.0083 & 0.0003 & 0.0050 & 0.0019 to 0.0080 & 0.0015 \\
\hline & Days since 2nd dose & 0.0039 & -0.026 to 0.033 & 0.80 & 0.015 & -0.0098 to 0.040 & 0.24 & -0.00057 & -0.011 to 0.0094 & 0.91 \\
\hline & COVID-19 convalescent & 0.16 & -0.087 to 0.42 & 0.20 & 0.23 & 0.0081 to 0.46 & 0.042 & 0.25 & 0.0061 to 0.50 & 0.045 \\
\hline \multirow{8}{*}{$\begin{array}{l}\text { Viral } \\
\text { neut } \\
\left(\log _{2}\right)\end{array}$} & Age (per year) & -0.018 & -0.033 to -0.0030 & 0.019 & -0.020 & -0.034 to -0.0052 & 0.008 & -0.0049 & -0.020 to 0.010 & 0.52 \\
\hline & Male sex & -0.33 & -0.85 to 0.18 & 0.21 & 0.22 & -0.30 to 0.75 & 0.40 & 0.25 & -0.20 to 0.71 & 0.27 \\
\hline & white Ethnicity & -0.075 & -0.59 to 0.43 & 0.77 & 0.27 & -0.24 to 0.78 & 0.30 & -0.024 & -0.48 to 0.44 & 0.92 \\
\hline & \# chronic cond. (per add'l) & -0.10 & -0.34 to 0.14 & 0.42 & -0.16 & -0.40 to 0.095 & 0.22 & 0.00081 & -0.21 to 0.22 & 0.99 \\
\hline & Spikevax as first dose & 0.86 & -0.098 to 1.82 & 0.078 & 0.71 & -0.30 to 1.7 & 0.17 & 0.92 & -0.053 to 1.89 & 0.064 \\
\hline & Dose interval (per day) & 0.0066 & -0.0044 to 0.018 & 0.24 & -0.00046 & -0.011 to 0.010 & 0.93 & 0.0036 & -0.0057 to 0.013 & 0.45 \\
\hline & Days since 2 nd dose & 0.0040 & -0.094 to 0.10 & 0.94 & -0.066 & -0.16 to 0.026 & 0.16 & -0.0038 & -0.036 to 0.028 & 0.81 \\
\hline & COVID-19 convalescent & 1.64 & 0.81 to 2.47 & 0.0001 & 1.84 & 1.0 to 2.7 & $<0.0001$ & 1.50 & 0.68 to 2.32 & 0.0005 \\
\hline
\end{tabular}

*for viral neutralization, reciprocal plasma dilutions were $\log _{2}$ transformed prior to multivariable analysis. 
Table 3: Multivariable analysis of the relationship between sociodemographic, health and vaccine-related variables on serum antibody half-life following two-dose COVID-19 mRNA vaccination

\begin{tabular}{llccc}
\hline Outcome measure & Variable & Estimate & $\mathbf{9 5 \%}$ CI & p-value \\
\hline Ab half-life after two vaccine doses & Age (per year) & 0.13 & -0.12 to 0.37 & 0.30 \\
(in days) & Male sex & 7.09 & -1.74 to 15.91 & 0.11 \\
& white Ethnicity & 5.53 & -3.26 to 14.31 & 0.22 \\
& \# chronic conditions (per add'l) & -6.02 & -10.16 to -1.89 & $\mathbf{0 . 0 0 4 6}$ \\
& Spikevax as first dose & -1.61 & -17.86 to 14.64 & 0.85 \\
& Dose interval (per day) & -0.00019 & -0.18 to 0.18 & 0.99 \\
& COVID-19 convalescent & 34.42 & 20.18 to 48.65 & $<\mathbf{0 . 0 0 0 1}$ \\
\hline
\end{tabular}


Figure 1

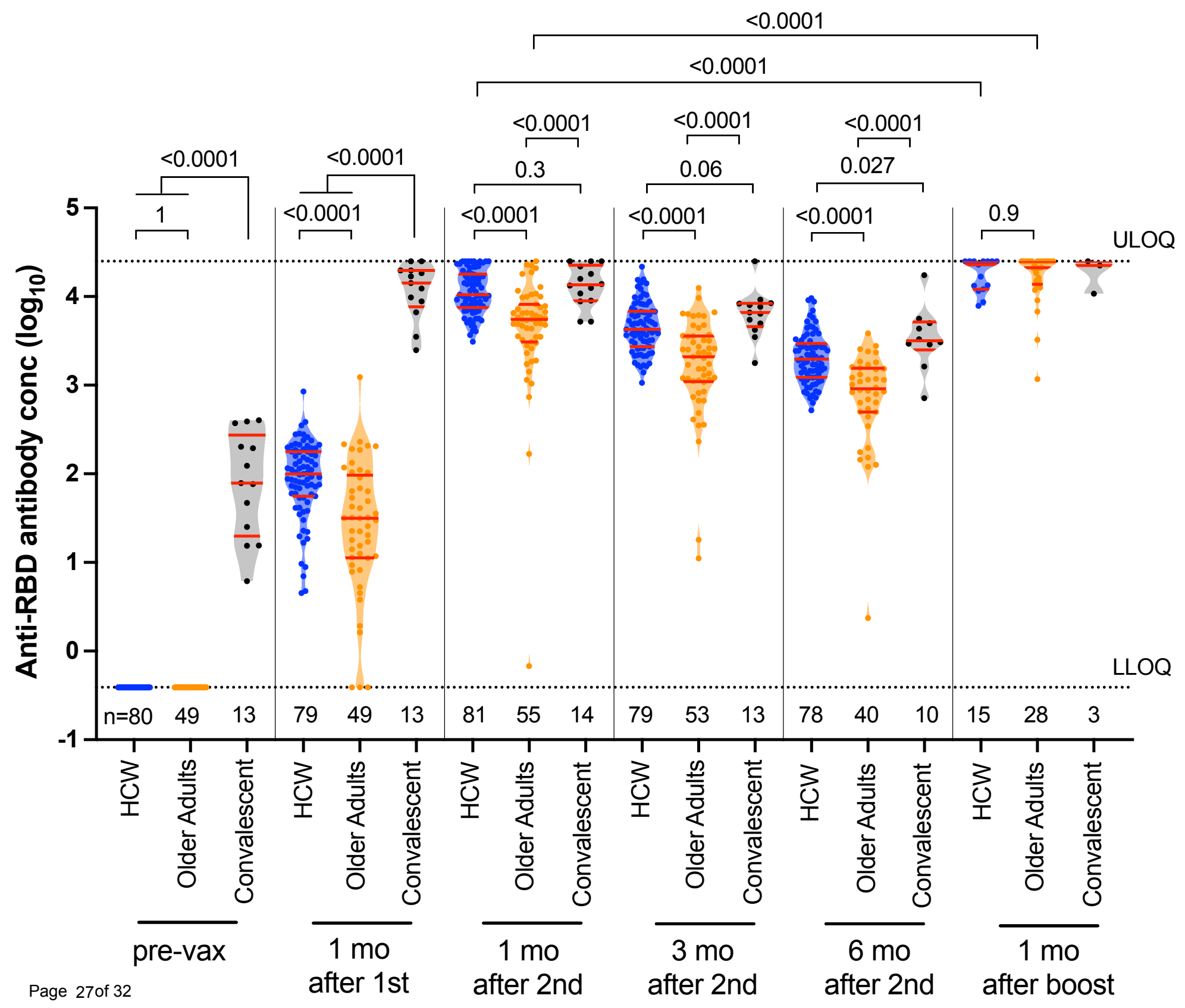


medRxiv preprint doi: https://doi.org/10.1101/2022.01.06.22268745; this version posted January 6, 2022. The copyright holder for this preprint (which was not certified by peer review) is the author/funder, who has granted medRxiv a license to display the preprint in perpetuity. It is made available under a CC-BY-NC-ND 4.0 International license.

\section{Figure 1. Longitudinal binding antibody responses to spike RBD following one, two and three}

COVID-19 vaccine doses. Binding antibody responses to the SARS-CoV-2 spike RBD in serum, in

HCW (blue circles) and older adults (orange circles) who were COVID-19 naive at study entry, as well as COVID-19 convalescent individuals (black circles) at six timepoints: prior to vaccination, one month following the first dose, one, three and six months following the second vaccine dose, and one month following the third or booster vaccine dose. The numbers of participants analyzed are indicated at the bottom of the plot. Red bars and whiskers represent the median and IQR. P-values were computed using the Mann-Whitney U-test (for comparisons between groups) or the Wilcoxon matched pairs test (for comparisons across time points within a group) and are uncorrected for multiple comparisons. LLOD: lower limit of detection. ULOQ: upper limit of quantification. 
Figure 2

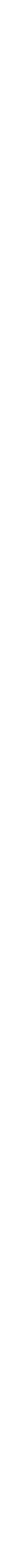


medRxiv preprint doi: https://doi.org/10.1101/2022.01.06.22268745; this version posted January 6, 2022. The copyright holder for this preprint (which was not certified by peer review) is the author/funder, who has granted medRxiv a license to display the preprint in perpetuity.

It is made available under a CC-BY-NC-ND 4.0 International license .

\section{Figure 2. Longitudinal live virus neutralization activity in plasma following one, two and three}

COVID-19 vaccine doses. Viral neutralization activities, defined as the lowest reciprocal plasma dilution at which neutralization was observed in all triplicate assay wells, in HCW (blue circles) and older adults (orange circles) who were COVID-19 naive at study entry, as well as COVID-19 convalescent participants (black circles) at six timepoints: prior to vaccination, one month following the first dose, one, three and six months following the second vaccine dose, and one month following the third or booster vaccine dose. Plasma samples showing neutralization in fewer than three wells at a $1 / 20$ dilution were coded as having a reciprocal dilution of 10 , corresponding to the lower limit of quantification (LLOQ) in this assay. The highest dilution tested was $1 / 2560$, which corresponds to the upper limit of quantification (ULOQ) in this assay. The numbers of participants analyzed are indicated at the bottom of the plot; note that only a subset of pre-vaccine plasma samples was assayed for this activity. Red bars and whiskers represent the median and IQR. P-values were computed using the Mann-Whitney U-test (for comparisons between groups) or the Wilcoxon matched pairs test (for comparisons across time points within a group) and are uncorrected for multiple comparisons. 


\section{Figure 3}

a

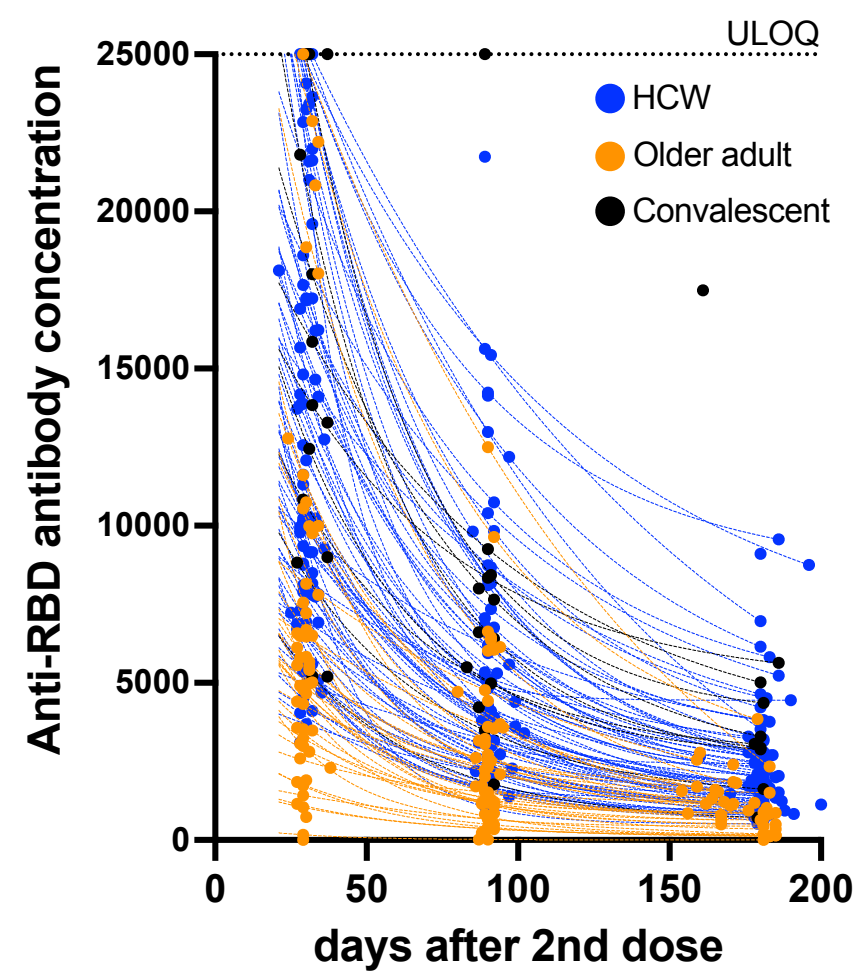

b

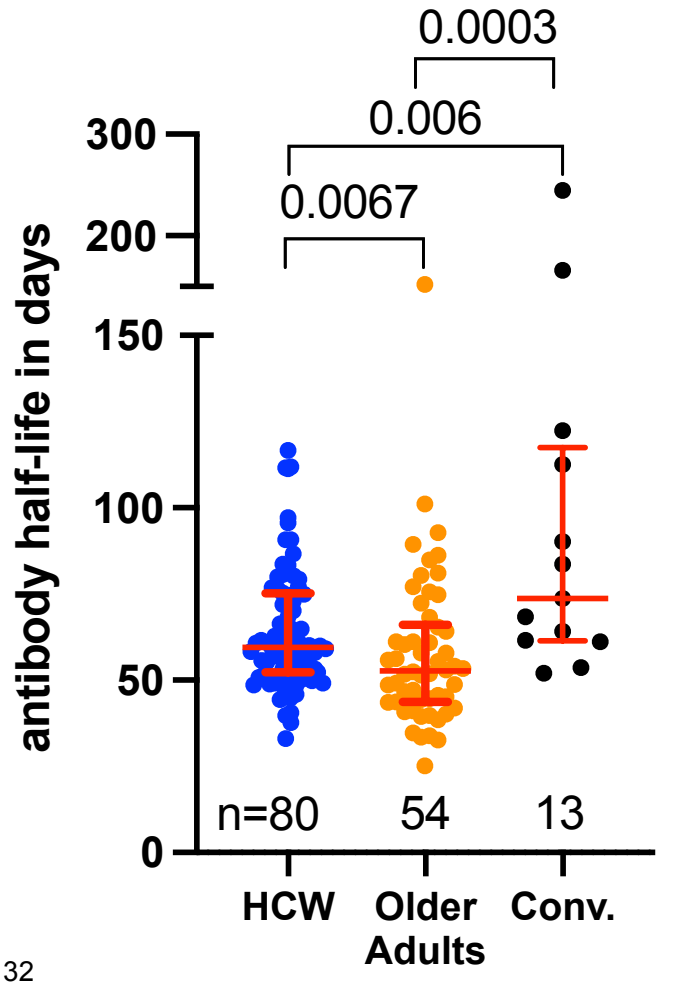


medRxiv preprint doi: https://doi.org/10.1101/2022.01.06.22268745; this version posted January 6, 2022. The copyright holder for this preprint (which was not certified by peer review) is the author/funder, who has granted medRxiv a license to display the preprint in perpetuity. It is made available under a CC-BY-NC-ND 4.0 International license.

Figure 3: Decay rates and half-lives of serum binding antibody responses to spike RBD following two COVID-19 vaccine doses. Panel A: Temporal declines in serum binding antibody responses to spike-RBD following two COVID-19 vaccine doses in HCW (blue) and older adults (orange) who were COVID-19 naive at study entry, as well as COVID-19 convalescent participants (black circles). ULOQ: upper limit of quantification. Panel B: Binding antibody half-lives following two COVID-19 vaccine doses, calculated by fitting an exponential curve to each participant's available longitudinal measurements shown in panel A. The numbers of participants analyzed are indicated at the bottom of the plot. Red bars and whiskers represent the median and IQR. P-values were computed using the Mann-Whitney U-test and are uncorrected for multiple comparisons. 